Ярослав Миколайович Костюченко, кандидат юридичних наук, адвокат, докторант Інституту міжнародних відносин Київського національного університету імені Тараса Шевченка*

ORCID: 0000-0002-2399-1535

\title{
КОНЦЕПТУАЛЬНІ ОСНОВИ ФУНКЦІОНУВАННЯ СПІЛЬНИХ ОРГАНІВ СПІВПРАЦІ, СТВОРЕНИХ УГОДОЮ ПРО АСОЦІАЦІЮ МІЖ УКРАЇНОЮ ТА ЄС
}

Постановка проблеми. Від початку існування незалежної української держави вона перейшла до нового етапу розвитку - створення стратегічних планів та пошуку партнерської підтримки. 3 тих пір починається час новітніх відносин з Свросоюзом та сусідніми державами. Хронологія подій характеризується плавністю переходу від декларацій політичного характеру, наданням допомоги технічного, економічного і фінансового плану до динаміки співпраці в усіх галузях. Таким відносинам притаманне поступове переростання до узгодженості намірів уряду і громадян та усвідомлення спільної діяльності у майбутньому, побудова прозорості кордонів, сприяння технічній, військовій, економічній безпеці тощо. Ухвалення Угоди про асоціацію між Україною та Європейським Союзом 2014 р. сприяло новому рівневі їхнього співробітництва. Успішній реалізації цілей, що визначені Угодою, значним чином допомагає інституційне забезпечення спільної діяльності.

Аналіз останніх досліджень і публікацій. Проблемам розвитку інституційної основи співробітництва України та СС присвячено досить широке коло праць. Зокрема, провідними науковцями даної тематики в Україні є Н. Гнидюк, М. Кузьо, С. Павлюк, О. Сушко, Р. Хорольський, Д. Черніков, О. Шпакович та інші. Разом із тим питання концептуальних основ функціонування спільних органів співпраці, створених угодою про асоціацію між Україною та ЄС, на сучасному етапі висвітлені недостатньо, що зумовило вибір теми даної статті.

Формулювання мети статті. Основною метою статті є з'ясування концептуальних основ функціонування спільних органів співпраці, створених угодою про асоціацію між Україною та ЄС (далі - УА).

Виклад основного матеріалу. Для ухвалення рішень задля імплементації Угоди про асоціацію між Україною та ЄС передбачається ії інституційний механізм. У ст. 217 Договору про функціонування Європейського Союзу 2009 р. йдеться про те, що «Союз може укладати з однією чи більше третіми країнами або міжнародними організаціями угоди про створення асоціації, які передбачають взаємні права й обов'язки, спільні діï $і$ особливі процедури»1․․ Окрім цього, зазначається, що угодами про асоціацію передбачено формування спеціальних механізмів для здійснення спільної діяльності. Цією характерною особливістю угод про асоціацію може засвідчуватися те, що кожною з таких угод має створюватися хоча б мінімальна інституційна структура, хоча інститути створюються і в рамках торгівельних угод. Через те, що угоди про асоціацію діють як рамкові, для їх імплементації відбувається створення спільних структур. Сторонами угод засновуються у рамках асоціації певні органи, що мають сприяти ухваленню асоційованими країнами СС рішень, які $є$ спільними, і цим же ефективно здійснювати керування асоціацією. Рішення асоціативних органів ухвалюються задля їх імплементації та сприяння майбутньому розвитку асоціативної угоди. Отже, відбувається формування інституційного механізму, що є сукупністю органів співробітництва, які формують угоди про асоціацію 3 Євросоюзом, даючи їм певні повноваження, що спільно сприяють реалізації певних завдань угод і допомагають досягти визначених ними цілей, та акти цих спільних органів.

Варто погодитися $з$ думкою О. Шпакович, яка зазначає, що в праві Європейського Союзу асоціація являє собою одну з правових форм відносин між $Є С$ та третіми країнами чи міжнародними організаціями,

\footnotetext{
() Я.М. Костюченко, 2019

${ }^{*}$ Yaroslav Kostyuchenko, Ph.D. in Law, doctoral student of the Institute of International Relations of Taras Shevchenko National University of Kyiv
}

Часопис Київського університету права • 2019/2 
яка не означає приєднання асоційованих країн чи міжнародних організацій до статуту співтовариства або Євросоюзу. Спільною метою будь-якої асоціації, а в даному випадку асоціації України з Свросоюзом, $\epsilon$ насамперед створення правових рамок для привілейованих відносин без визначення чітких правил щодо можливого змісту таких відносин. Складовою економічною частиною угод про асоціацію $є$ зона вільної торгівлі (далі - 3ВТ). Ступінь співпраці між ЄС і третіми країнами в межах асоціації неоднаковий і залежить як від цілей асоціації, так і від рівня економічного та політичного розвитку третьої країниㄹ․

Інституційна структура співробітництва України та СС визначена в розділі VII «Інституційні, загальні та прикінцеві положення» Угоди про асоціацію. За основу було взято вже відпрацьовану у попередні роки схему, і в Угоді про асоціацію встановлено наступну інституційну структуру:

- Рада асоціації;

- Комітет асоціації;

- Парламентський комітет асоціації;

- Платформа громадянського суспільства ${ }^{3}$. (табл. 1).

Спробуємо узагальнити та доповнити перелік та функції інституцій співробітництва України та ЄС

Функції інституцій співробітництва України та ЄС

Таблиияя 1

\begin{tabular}{|c|c|c|}
\hline $\begin{array}{c}№ \\
\text { 으 }\end{array}$ & Назва органу & Функції \\
\hline 1 & Саміт & $\begin{array}{l}\text { Відбувається один раз протягом року. В той час, коли тривають саміти, піддають } \\
\text { загальному нагляду імплементації Угоди та обговорення питань двостороннього } \\
\text { або міжнародного характеру, що мають спільний інтерес. }\end{array}$ \\
\hline 2 & Рада асоціації & $\begin{array}{l}\text { Відбувається з частотою не менше, ніж раз на рік, запроваджуючи свій регламент } \\
\text { та маючи склад із членів Ради Свросоюзу, членів СК (Сторони Свросоюзу) та } \\
\text { членів українського уряду (української сторони). Радою здійснюється контролю- } \\
\text { вання, також вдається до моніторингу і періодичного здійснення функціонально- } \\
\text { го огляду імплементація Угоди згідно з контекстом досягнення її цілей. }\end{array}$ \\
\hline 3 & Комітет асоціації & $\begin{array}{l}\text { Є допоміжним органом Ради асоціації. Асоціативним комітетом проводиться } \\
\text { засідання не рідше, аніж раз на рік, складаючись із членів Ради Євросоюзу, чле- } \\
\text { нів ЄК (Сторони Євросоюзу), та членів українського уряду (української сторо- } \\
\text { ни) - старших посадових осіб. Головами асоціативного Комітету є по черзі Сто- } \\
\text { рони Свросоюзу та Українська сторона. Основні завдання Комітету полягають в } \\
\text { підготовці скликань Ради. }\end{array}$ \\
\hline 4 & $\begin{array}{l}\text { Парламентський } \\
\text { комітет асоціації }\end{array}$ & $\begin{array}{l}\text { Виступає форумом для взаємного обміну думок, до якого зараховуються члени } \\
\text { Європейського парламенту, з одного боку, та парламенту України, з іншого. Голо- } \\
\text { вування у Комітеті парламенту з асоціації є почерговим для представників таких } \\
\text { структур, як Європейський парламент та Український парламент відповідно до } \\
\text { положень, які передбачаються власним регламентом. Разом із тим Парламент- } \\
\text { ським комітетом може вимагатися певна інформація щодо імплементації Угоди у } \\
\text { Ради асоціації та запитуватися інформація про рішення цих питань та надання } \\
\text { рекомендацій. Парламентським комітетом можуть надаватися особисті рекомен- } \\
\text { дації для Ради асоціації. }\end{array}$ \\
\hline 5 & $\begin{array}{l}\text { Платформа грома- } \\
\text { дянського суспіль- } \\
\text { ства }\end{array}$ & $\begin{array}{l}\text { Створена задля упровадження зустрічей, які були б регулярними між сторонами } \\
\text { суспільств, що є громадянськими. Платформі суспільств громадянського типу } \\
\text { притаманний склад, що представлений Свропейським економічним та соціаль- } \\
\text { ним комітетом та представниками українського суспільства, що є громадян- } \\
\text { ським.Головами по черзі є особи, які представляють Європейський економічний } \\
\text { та соціальний комітет та представники українського громадянського суспільства } \\
\text { відповідно до положень, що будуть передбачатися правилами механізму. Коміте- } \\
\text { том асоціації та Парламентським комітетом з асоціації регулярно організовують- } \\
\text { ся зв’язки з особами, що представляють Платформу громадянського суспільства } \\
3 \text { питань досягнення цілей Угоди. }\end{array}$ \\
\hline
\end{tabular}


Угода робить акцент на тому, що політичному діалогові та діалогові з політичних питань найвищого рівня між учасниками має бути відведено спеціальне місце - під час самітів, які проводять, зазвичай, раз на рік. На них здійснюється загальний нагляд за Угодою та обговорення будь-яких двосторонніх або міжнародних питань, що підлягають взаємному інтересові. Так, перший саміт Україна - СС в рамках Угоди відбувся 27 квітня 2015 р., а останній, двадцять перший саміт Україна - СС - 8 липня 2019 року. На ньому були розглянуті питання боротьби з корупцією, продовження санкцій проти Росії та повернення Росії в ПАРЄ 4 .

На міністерському рівні політичні діалоги та діалоги з політичних питань проводяться в межах Ради асоціації та в межах зустрічей, що є регулярними для представників обох сторін при взаємній згоді. На Раду асоціації покладають реалізацію контролю і моніторингу дотримання Угоди й періодичний перегляд іiі дії у контексті передбачених цілей. Окрім цього, Радою можуть вивчатися будь-які важливі питання, що діють у межах, визначених Угодою, та решта будь-яких двосторонніх або міжнародних питань, у яких сторони взаємно заінтересовані. Засідання Ради асоціації мають проводитися регулярно на рівні міністрів щонайменше один раз на рік, а також тоді, коли цього вимагають обставини. Відповідно до ст. 462 УА Рада складається 3 членів Уряду України та членів Ради СС і Європейської Комісії, хоча за взаємною згодою їі засідання можуть проводитися у будь-якому складі. Головування в Раді здійснюється по черзі представниками України та ЄС. Рада асоціації встановлює власний регламент 5

3 метою досягнення цілей УА Рада має повноваження для ухвалення обов'язкових для учасників рішень в межах рамок, в яких діс Угода. Радою можуть надаватися і рекомендації. Відповідно до мети поступового наближення законодавства України до права ЄС Рада асоціації має бути форумом для обміну інформацією про законодавчі акти України та ЄС: чинні та ті, що перебувають на стадії підготовки, а також про заходи $з$ їхього виконання, застосування та дотримання. 3 цією метою Рада може актуалізувати або вносити поправки до додатків Угоди, враховуючи розвиток права ЄС і стандартів, що застосовуються, та, на думку сторін, безпосередньо цього стосуються 6 .

Перше засідання новоствореної Ради асоціації відбулося 15 грудня 2014 р., а четверте - перше після набуття чинності Угодою про асоціацію - 8 грудня 2017 року. Учасниками засідання було підтримано українську інституційну та нормативно-правову базу, щоб посилити імплементацію, координацію та моніторинг реалізації Угоди про асоціацію, обговорюючи реформування в межах України, в тому числі тих питань, що торкаються децентралізації, реформи держуправління, судової системи, боротьби з проявами корупції, торговельно-економічного співробітництва відповідно до поглиблення та всеосяжності зони, що передбачає вільну торгівлю та поновлення суверенітету і неподільності української території. Серед рішень практичного характеру: в Україні за підсумками скликання стало вкладання двох угод: про надавання з боку Єврокомісії 50 млн євро для посилення владних органів на місцях, відновлення економіки, безпеки громадян та соціального згуртовування на території Донбасу і ще 5 млн євро - щоб розвивати Дунайський регіон ${ }^{7,8}$.

Згідно зі ст. 464 УА, для допомоги Раді асоціації у виконанні ії обов'язків засновується Комітет асоціації, який складається з представників обох сторін, головним чином на рівні вищих посадових осіб. Головування в Комітеті здійснюється по черзі представниками України та СС. Обов'язки і порядок функціонування Комітету, до сфери відповідальності якого належить підготовка засідань Ради асоціації, визначає в своєму регламенті Рада. Вона може делегувати Комітету будь-яке зі своїх повноважень, зокрема повноваження ухвалювати обов'язкові для виконання рішення. Комітет асоціації проводить засідання у спеціальному складі для вирішення всіх питань, пов'язаних із Розділом IV (Торгівля і питання, пов'язані з торгівлею) Угоди. Засідання у цьому складі Комітет проводить щонайменше один раз на рік9.

У грудні 2014 р., напередодні першого засідання Ради асоціації, Кабінет Міністрів України своєю постановою від 10 грудня 2014 р. № 700 «Питання підготовки та проведення засідань окремих двосторонніх органів асоціації між Україною та ЄС» визначив, що від України членами Ради асоціації $є$ члени Кабінету Міністрів, а Комітету асоціації - заступники міністрів із питань європейської інтеграції, директор Урядового офісу з питань європейської та євроатлантичної інтеграції Секретаріату Кабінету Міністрів України, заступник міністра економічного розвитку і торгівлі - Торговий представник України, заступники керівників інших центральних органів виконавчої влади, до повноважень яких належать питання виконання Угоди про асоціацію. Перше засідання Комітету асоціації відбулося 13-14 липня 2015 р., а перше засідання Комітету асоціації у торговельному складі - у квітні 2016 року10,11,12.

Комітет асоціації отримує допомогу з боку підкомітетів. Радою асоціації можуть прийматися рішення про створювання будь-яких спеціальних комітетів чи органів у відповідних сферах, що є необхідними для реалізації Угоди, і визначаються склад, перелік обов'язків і послідовність діяльності, що провадиться такими органами. Комітет асоціації може також створювати підкомітети для вивчення прогресу, досягнутого у ході регулярних діалогів, визначених у Розділі V (Економічне і галузеве співробітництво) Угоди. Підкомітети мають повноваження приймати рішення у випадках, передбачених Угодою. Вони регулярно та в міру необхідності звітують про свою діяльність Комітету асоціації у торговельній конфігурації. Рішенням Ради асоціації № 2/2014 від 15 грудня 2014 р. було утворено два підкомітети: Підкомітет із питань свободи, безпеки та юстиції і Підкомітет із питань економіки та іншого галузевого співробітництва ${ }^{13}$.

Згідно з домовленістю Сторін, за підсумками першого засідання Комітету асоціації (13-14 липня 2015 р.), діяльність підкомітету з питань економіки та іншого галузевого співробітництва має здійснюватися за кластерним принципом - з фокусом на ключові питання, які закріплені за підкомітетом (табл. 2). 
Кластери Комітету асоціації

\begin{tabular}{|c|l|}
\hline Назва кластеру & \multicolumn{1}{|c|}{ Напрям } \\
\hline Кластер 1 & $\begin{array}{l}\text { Макроекономічне співробітництво, управління державними фінансами (бюджетна } \\
\text { політика, внутрішній контроль та зовнішній аудит, статистика, облік і аудит, боротьба } \\
\text { 3 шахрайством) }\end{array}$ \\
\hline Кластер 2 & $\begin{array}{l}\text { Промислова та підприємницька політика, гірнича справа і металургія, туризм, космос, } \\
\text { законодавство про товариства та корпоративне управління, захист прав споживачів, } \\
\text { оподаткування }\end{array}$ \\
\hline Кластер 3 & $\begin{array}{l}\text { Співробітництво у сфері енергетики, включаючи ядерні питання, навколишне природ- } \\
\text { не середовище, включаючи зміну клімату та цивільний захист, транспорт }\end{array}$ \\
\hline Кластер 4 & $\begin{array}{l}\text { Співробітництво у сфері науки та технологій, інформаційне суспільство, аудіовізуаль- } \\
\text { на політика, освіта, навчання та молодь, культура, співробітництво в галузі спорту та } \\
\text { фізичної культури }\end{array}$ \\
\hline Кластер 5 & $\begin{array}{l}\text { Сільське господарство та розвиток сільських районів, рибальство та морська політика, } \\
\text { Дунайський регіон, транскордонне та регіональне співробітництво }\end{array}$ \\
\hline Кластер 6 & $\begin{array}{l}\text { Співробітництво в галузі зайнятості, соціальної політики та рівних можливостей, охо-- } \\
\text { рона здоров’я }\end{array}$ \\
\hline
\end{tabular}

Джерело: складено за даними ${ }^{14,15}$.

Крім того, безпосередньо положеннями Угоди про асоціацію передбачено створення:

- Підкомітету з географічних зазначень (ст. 211 Угоди),

- Підкомітету з управління санітарними та фітосанітарними заходами (ст. 74 Угоди),

- Підкомітету з питань митного співробітництва (ст. 83 Угоди);

- Підкомітету з питань торгівлі та сталого розвитку (ст. 300 Угоди) $16,17,18$

Застосування політичного діалогу на рівні Парламенту, згідно зі ст. 467 Угоди, орієнтується на рамки, які визначив Парламентський комітет асоціації, у склад якого входять члени ВР України та Європейського Парламенту. Ним встановлюється свій регламент. Головами комітету є усі по черзі представники сторін. Скликання проводять настільки регулярно, наскільки він сам визначить. У парламентського комітету асоціації $є$ право для запиту у Ради асоціації відповідної інформації про впровадження засад Угоди, він повинен бути поінформованим органами Ради про іiі рішення та наявні рекомендації. Комітетом можуть надаватися власні рекомендації для Ради та утворювати певні підкомітети. Першим засіданням, яке проводив Парламентський комітет асоціації, було скликання 24-25 лютого 2015 р. на території Брюсселю, а 20 вересня 2017 р. у Дніпрі за спільного головування Миколи Княжицького з боку ВР України та з боку Даріуша Росаті від імені Свропарламенту. Це було шосте засідання Парламентського комітету асоціації між представниками України та Євросоюзу19,20,21.

Згідно зі ст. 469 УА, сторони якої повинні сприяти регулярним засіданням осіб, що представляють їхнє громадянське суспільство задля поінформованості їх про втілення Угоди та враховуючи їхній внесок для іiі реалізації. Відповідно до цієї мети передбачають створення Платформи громадянського суспільства (далі ПГС), що включає осіб, які є представниками українського суспільства, що є громадянським, та членів (Свропейського економічного і соціального комітету (далі - СЕСК). Вона повинна мати характер форуму задля проведення зустрічей та обміну думок.

Платформа громадянського суспільства характеризується своїм власним регламентом і проведенням засідань, самостійно визначеною регулярністю. Головами у ПГС по черзі є представники громадянського суспільства від України та представників ЄЕСК. ПГС має бути забезпечена інформацією про рішення та надання рекомендацій Радою асоціації і може надавати рекомендації. Комітетом асоціації та Парламентським комітетом асоціації має регулярно здійснюватися зв'язок з особами, які представляють ПГС, щоб отримати їхню думку про досягання цілей Угоди.

Українська сторона Платформи громадянського суспільства почала утворюватися у травні 2014 р., коли через публічне обговорення відбулося створення Оргкомітету. У листопаді 2014 р. було проведено Установчі збори УС ПГС, де більш ніж 165 громадськими організаціями, які є представниками всього спектру українського громадянського суспільства, було обрано 15 членів, які представляли різні сектори соціуму - громадські об'єднання, профспілки та організації роботодавців. На установчому засіданні ПГС, яке вважається двостороннім органом, 16 квітня 2015 р. у Києві затвердили Регламент ПГС. У 2016 р. ПГС було проведено два засідання - в місті Брюссель у лютому і в Києві у листопаді, на яких, окрім того, що обговорювали прогpec реалізації Угоди про асоціацію, було представлено низку тематичних доповідей Платформи 22,23 .

Висновки. Проаналізувавши те, як розвивалася інституційна основа у співробітництві між Україною та Європейським Союзом, можна побачити, що під час їхньої співпраці відбулося формування ефективної інституційної структури підтримки співробітництва, завдяки якій можлива успішна реалізація завдань, визначених в Угоді про асоціацію між Україною та ЄС. Щоб успішно реалізувати євроінтеграційні реформи в нашій країні, потрібна наявність певних передумов, у тому числі політичної волі та інституційної спроможності державного 
апарату. В української влади є політична воля для модернізації системи. Стосовно того, наскільки спроможним $\epsilon$ державний апарат, до євроінтеграційного процесу відбулося залучення Урядового офісу 3 питань євроінтеграції, секторальних міністерств, парламентського Комітету з питань європейської інтеграції. Представництвом Євросоюзу проводиться тісна співпраця з Урядовим офісом з метою зміцнення інституційної спроможності. Як бачимо, Україна має активне громадянське суспільство, яке займається постійним моніторингом роботи владних структур. Загальними цілями подальшого реформування залишаються покращення життєвих стандартів громадян, модернізація України, забезпечення ії демократичної стабільності та економічного росту.

1 Договір про Європейський Союз від 07.02.1992 p. URL: https://zakon.rada.gov.ua/laws/show/994_029

2 Шпакович О.М. Інституційний механізм в рамках Угоди про асоціацію України з Європейським Союзом. Актуальні проблеми міжнародних відносин. 2013. Вип. 115(2). С. 23-28.

3 Угода про асоціацію між Україною, з однієї сторони, та Європейським Союзом і його державами-членами, з іншої сторони. URL: http://zakon4.rada.gov.ua/laws/show/984_011/page

4 Заява Зеленського за підсумками саміту Україна - СС: основні тези. URL: https://24tv.ua/zelenskiy_zrobiv_pidsumkovu_ zayavu pro_samit ukrayina yes n1176582

5 Угода про асоціацію між Україною, з однієї сторони, та Свропейським Союзом і його державами-членами, 3 іншої сторони. URL: http://zakon4.rada.gov.ua/laws/show/984_011/page

6 Угода про асоціацію між Україною, з однієї сторони, та Європейським Союзом і його державами-членами, з іншої сторони. URL: http://zakon4.rada.gov.ua/laws/show/984_011/page

7 Звіт про виконання Порядку денного асоціації та Угоди про асоціацію між Україною та Свропейським Союзом (січень жовтень 2015 року). URL: https://www.kmu.gov.ua/storage/app/media/zviti-pro-vikonannya/aaaag-goei-report-january-october-2015final-version011215071215. pdf

8 Спільна заява Прем'єр-міністра України Володимира Гройсмана і Високого представника ЄС із закордонних справ і безпекової політики Федеріки Могеріні за результатами 4-го засідання Ради асоціації між Україною та Свропейським Союзом. URL: http://mfa.gov.ua/ua/press-center/news/61765-spilyna-zajava-premjerministra-ukrajini-volodimira-grojsmana-i-visokogo-pred stavnika-jes-iz-zakordonnih-sprav-i-bezpekovoji-politikifederiki-mogerini-za-rezulytatami-4-go-zasidannya-radi-asociaciji-mizhukrajinoju-ta-jevropejsykim-sojuzom

9 Угода про асоціацію між Україною, з однісї сторони, та Європейським Союзом і його державами-членами, 3 іншої сторони. URL: http://zakon4.rada.gov.ua/laws/show/984_011/page

10 Звіт про виконання Угоди про асоціацію між Україною та Європейським Союзом в 2016 році. URL: https://www.kmu. gov.ua/storage/app/media/zviti-pro-vikonannya/zvit-pro-assotsiatsiyu-2016.pdf

${ }^{11}$ Комітет асоціації. URL: https://www.kmu.gov.ua/ua/diyalnist/yevropejska-integraciya/vikonannyaugodi-pro-asociaciyu/ dvostoronni-organi-asociaciyi-ukrayina-yes/komitet-asociaciyi

12 Питання підготовки та проведення засідань окремих двосторонніх органів асоціації між Україною та ЄС: постанова Кабінету Міністрів України від 10 грудня 2014 р. № 700. URL: http://zakon1.rada.gov.ua/laws/ show/700-2014-\%D0\%BF

13 Угода про асоціацію між Україною, з однієї сторони, та Європейським Союзом і його державами-членами, $з$ іншої сторони. URL: http://zakon4.rada.gov.ua/laws/show/984_011/page

14 Звіт про виконання Порядку денного асоціації та Угоди про асоціацію між Україною та Європейським Союзом за 2015 рік. URL: https://www.kmu.gov.ua/storage/app/media/zviti-pro-vikonannya/AA_GOEI_REPORT_Dec_2015_final_February_ukr.pdf

15 Підкомітети. URL: https://www.kmu.gov.ua/ua/diyalnist/yevropejska-integraciya/vikonannya-ugodipro-asociaciyu/dvostoronni-organi-asociaciyi-ukrayina-yes/pidkomiteti

16 Звіт про виконання Порядку денного асоціації та Угоди про асоціацію між Україною та Європейським Союзом за 2015 рік. URL: https://www.kmu.gov.ua/storage/app/media/zviti-pro-vikonannya/AA_GOEI_REPORT_Dec 2015 final_February_ukr.pdf

17 Підкомітети. URL: https://www.kmu.gov.ua/ua/diyalnist/yevropejska-integraciya/vikonannya-ugodipro-asociaciyu/dvostoronni-organi-asociaciyi-ukrayina-yes/pidkomiteti

18 Угода про асоціацію між Україною, з однієї сторони, та Європейським Союзом і його державами-членами, з іншої сторони. URL: http://zakon4.rada.gov.ua/laws/show/984_011/page

19 Звіт про виконання Порядку денного асоціації та Угоди про асоціацію між Україною та Європейським Союзом за 2015 рік. URL: https://www.kmu.gov.ua/storage/app/media/zviti-pro-vikonannya/AA_GOEI_REPORT_Dec_2015 final_February_ukr.pdf. 43508.pdf

20 Парламентський комітет асоціації Україна - EC. Шосте засідання. URL: http://iportal.rada.gov.ua/uploads/documents/

21 Угода про асоціацію між Україною, з однієї сторони, та Європейським Союзом і його державами-членами, 3 іншої сторони. URL: http://zakon4.rada.gov.ua/laws/show/984_011/page

22 Звіт про виконання Порядку денного асоціації та Угоди про асоціацію між Україною та Європейським Союзом за 2015 рік. URL: https://www.kmu.gov.ua/storage/app/media/zviti-pro-vikonannya/AA_GOEI_REPORT_Dec_2015_final_February_ukr.pdf

${ }^{23}$ Створено громадянську платформу, передбачену Угодою про асоціацію. URL: http://www. eurointegration.com.üa/news/ 2014/11/7/7027549/

\section{References:}

Treaty on European Union of 7 February 1992. Retrieved from: https://zakon.rada.gov.ua/laws/show/994_029 [in Ukraine].

Zelensky's statement following the Ukraine-EU summit: main points. Retrieved from: https://24tv.ua/zelenskiy_zrobiv_pidsumkovu_zayavu_pro_samit_ukrayina_yes_n1176582 [in Ukraine].

Report on the implementation of the Association Agenda and the Association Agreement between Ukraine and the European Union (January - October 2015). Retrieved from: https://www.kmu.gov.ua/storage/app/media/zviti-pro-vikonannya/aaaag-goei-reportjanuary-october-2015-final-version0112150712 15.pdf [in Ukraine].

Report on implementation of the Association Agenda and Association Agreement between Ukraine and the European Union for 2015. Retrieved from: https://www.kmu.gov.ua/storage/app/media/zviti-pro-vikonannya/AA_GOEI_REPORT_Dec_2015_final_February_ukr.pdf [in Ukraine]. 
Report on the implementation of the Association Agreement between Ukraine and the European Union (September 2014 - January 2015). Retrieved from: https://www.kmu.gov.ua/storage/app/media/zviti-pro-vikonannya/AA_impl_report_02_2015_GOEI.pdf [in Ukraine].

Report on the implementation of the Association Agreement between Ukraine and the European Union in 2016. Retrieved from: https://www.kmu.gov.ua/storage/app/media/zviti-pro-vikonannya/zvit-pro-assotsiatsiyu-2016.pdf [in Ukraine].

The Association Committee. Retrieved from: https:/www.kmu.gov.ua/ua/diyalnist/yevropejska-integraciya/vikonannyaugodipro-asociaciyu/dvostoronni-organi-asociaciyi-ukrayina-yes/komitet-asociaciyi [in Ukraine].

Parliamentary Committee of the Ukraine-EU Association. The sixth meeting. Retrieved from: http://iportal.rada.gov.ua/ uploads/documents/43508.pdf [in Ukraine].

Issues of preparation and holding of meetings of separate bilateral bodies of the Association between Ukraine and the EU: resolution of the Cabinet of Ministers of Ukraine of December 10, 2014 No. 700. Retrieved from: http://zakon1.rada.gov.ua/laws/show/ 700-2014-\%D0\%BF [in Ukraine].

Subcommittees. Retrieved from: https:/www.kmu.gov.ua/ua/diyalnist/yevropejska-integraciya/vikonannya-ugodipro-asocia ciyu/dvostoronni-organi-asociaciyi-ukrayina-yes/pidkomiteti [in Ukraine].

Joint statement by Prime Minister of Ukraine Volodymyr Groysman and EU High Representative for Foreign Affairs and Security Policy Federica Mogherini following the 4th session of the Association Council between Ukraine and the European Union. Retrieved from: http://mfa.gov.ua/ua/press-center/news/61765-spilyna-zajava-premjerministra-ukrajini-volodimira-grojsmana-i-visokogo-pred stavnika-jes-iz-zakordonnih-sprav-i-bezpekovoji-politikifederiki-mogerini-za-rezulytatami-4-go-zasidannya-radi-asociaciji-mizhukrajinoju-ta-jevropejsykim-sojuzom [in Ukraine].

The civic platform established by the Association Agreement has been created. Retrieved from: http://www.eurointegration.com. ua/news/2014/11/7/7027549 [in Ukraine].

Association Agreement between Ukraine, of the one part, and the European Union and its Member States, of the other part. Retrieved from: http://zakon4.rada.gov.ua/laws/show/984_011/page [in Ukraine].

Shpakovych, O. M. (2013). Institutional Mechanism in the framework of the Agreement on Association of Ukraine with the European Union. Aktual'ni problemy mizhnarodnykh vidnosyn. 115 (2) [in Ukraine].

\section{Резюме}

Костюченко Я.М. Концептуальні основи функціонування спільних органів співпраці, створених Угодою про асоціацію між Україною та СС.

У статті з'ясовано, що угодами про асоціацію передбачено формування спеціальних механізмів для здійснення спільної діяльності. Цією характерною особливістю угод про асоціацію може засвідчуватися те, що кожною з таких угод повинна створюватися хоча б мінімальна інституційна структура, хоча насправді інститути створюються і в рамках торгівельних угод. 3'ясовано, що наразі відбувається формування інституційного механізму, що є сукупністю органів співпраці, які формують угоди про асоціацію з Свросоюзом, даючи їм певні повноваження, що спільно сприяють реалізації певних задач угод і допомагають досягти визначених ними цілей, та акти цих спільних органів. Охарактеризовано функції інституцій співробітництва України та $€ С$, а також основні засади їх діяльності.

Ключові слова: інституційна структура, органи співпраці, угода про асоціацію, Європейський Союз, громадянське суспільство.

\section{Резюме}

Костюченко Я.Н. Концептуальные основы функционирования совместных органов сотрудничества, созданных соглашением об Ассоциации между Украиной и ЕС.

В статье установлено, что соглашениями об ассоциации предусмотрено формирование специальных механизмов для осуществления совместной деятельности. Эта характерная особенность соглашений об ассоциации может свидетельствовать о том, что каждой из таких соглашений должна создаваться хотя бы минимальная институциональная структура, хотя в действительности институты создаются и в рамках торговых соглашений. Выявлено, что сейчас происходит формирование институционального механизма, представляющего собой совокупность органов совместного сотрудничества, которые формируют соглашения об ассоциации с Евросоюзом, давая им определенные полномочия, совместно способствуют реализации определенных заданий соглашений и помогают достичь определенных ими целей, и акты этих совместных органов. Охарактеризованы функции институтов сотрудничества Украины и ЕС, а также основные принципы их деятельности.

Ключевые слова: институционная структура, органы сотрудничества, соглашение об ассоциации, Европейский Союз, гражданское общество.

\section{Summary}

Yaroslav Kostyuchenko. Conceptual basis for the functioning of the joint cooperation bodies established by the EUUkraine Association Agreement.

The article is devoted to the formation of special mechanisms for joint activities under the Association Agreements. This element of association agreements certify that for each such agreement there should be at least one minimal institutional structure, although in reality institutions are created also within the framework of trade agreements. Since the Association Agreements acts as a framework agreement, joint structures are established for their implementation. These are certain bodies to facilitate the adoption of common decisions how to cooperate for implementation and to promote the future developments and effectively manage the association. The article further investigates the functions of these cooperation institutions as well as the basic principles of their activity.

Since its independence Ukraine has never stopped the process of creating new alliances and search for cooperation partners. In doing so, it gradually shifted from political declarations and being a recipient of technical, economic and financial aid towards cooperation in all these spheres. The latter type can be characterized by clear vision of future, common position of government and citizens, creation of transparency at the boarders and fostering of technical, economic and military security etc. Adoption of Association Agreement between the EU and Ukraine in 2014 brought cooperation between them to a new level since the institutional mechanism set forth 
by the Agreement is of great help in reaching its goals. This mechanism, although still being created, should result into the full-functioning bodies under the Agreement for its better and faster execution. The author further gives the characteristics to these institutions of cooperation and proves the effectiveness of this structure to support and increase in effectiveness of cooperation that would lead to successful implementation. At the same time, the special attention is drawn to additional special conditions needed on the side of Ukraine to make the Agreement work, in particular political will and capabilities of state servants. Although the will is declared and additional bodies, such as Governmental office on European integration, were formed the process is lagging behind. The author believes that civil society that demonstrated its power during recent years would closely monitor integration process and may become a key success factor because the reforms are still aimed at increasing the living standards, modernization of the country, democratic stability and economic growth.

Key words: institutional structure, cooperation bodies, association agreement, the European Union, civil society.

DOI: 10.36695/2219-5521.2.2019.37

УДК 341.63

\section{В.Н. ПЕТРИНА}

Володимир Нестерович Петрина, кандидат юридичних наук, доцент Національної академії внутрішніх справ*

ORCID: 0000-0002-1093-7089

\section{ТЕРМІНОЛОГІЧНІ ПРОБЛЕМИ В УКРАЇНСЬКОМУ ЗАКОНОДАВСТВІ ПРО МІЖНАРОДНИЙ КОМЕРЦІЙНИЙ АРБІТРАЖ}

Постановка проблеми. Арбітраж $є$ найбільш поширеним шляхом вирішення спорів, що виникають у рамках міжнародних комерційних відносин. У цьому зв'язку важливо, щоб норми, які регулюють відносини у сфері міжнародного комерційного арбітражу, в усіх країнах світу були гармонізовані для того, щоб суб'єкти міжнародних комерційних відносин будь-яких країн, вдаючись до арбітражу для вирішення спорів між ними, однаково розуміли ці норми в силу їх уніфікованості.

Необхідність гармонізації усіма країнами світу законодавства про міжнародний комерційний арбітраж визнана в документах Організації Об'єднаних Націй, зокрема в резолюції Генеральної Асамблеї ООН № 40/72 від 11 грудня 1985 р., якою було схвалено Типовий закон про міжнародний комерційний арбітраж (англ. UNCITRAL Model Law on International Commercial Arbitration), розроблений Комісією ООН з права міжнародної торгівлі (UNCITRAL), та рекомендовано усім країнам-членам ООН врахувати положення цього типового закону з метою уніфікації законодавства цих країн з міжнародного комерційного арбітражу1.

На підставі вищезазначеної резолюції Генеральної Асамблеї ООН практично кожна країна-член $\mathrm{OOH}$ прийняла свій власний закон про міжнародний комерційний арбітраж, в основу якого було покладено вищезгаданий Типовий закон Юнсітрал про міжнародний комерційний арбітраж (далі - Типовий Закон Юнсітрал). Україна 24 лютого 1994 р. також прийняла такий закон, а саме Закон України «Про міжнародний комерційний арбітраж» (далі - ЗУ про МКА), зазначивши в його преамбулі, що «цей Закон ... враховує положення про такий арбітраж, які є в міжнародних договорах Украйни, а також в типовому законі, прийнятому в 1985 році Комісією ООН з права міжнародної торгівлі і схваленому Генеральною Асамблеєю ООН для можливого використання державами у своєму законодавстві»².

Проте, прийнявши ЗУ про МКА, Україна все ж таки не достатньою мірою досягла цілей гармонізації свого законодавства про міжнародний комерційний арбітраж з нормами міжнародного права. Норми ЗУ про МКА часом суттєво відрізняються від положень, передбачених Типовим Законом Юнсітрал, і головним чином це стосується термінології, що застосовується в ЗУ про МКА. Навіть саме поняття «арбітраж» в ЗУ про МКА концептуально відрізняється від поняття «арбітраж» (англ. arbitration), що застосовується в актах міжнародного права та права економічно розвинутих країн.

Такий стан речей в українському законодавстві про міжнародний комерційний арбітраж, яке $є$ частиною законодавства України із врегулювання господарських спорів, призводить до того, що Україна займає нижні сходинки у відповідних світових рейтингах. Так, наприклад, за таким показником, як «efficiency of legal framework in settling disputes» (що українською можна перекласти, як ефективність/якість/точність нормативно-правових актів, спрямованих на вирішення спорів) у Звіті про глобальну конкурентоспроможність (англ. the Global Competitiveness Report) за 2018 р. Україна посіла 103 місце із 140 країн, що досліджувалися³ До того ж, завдяки цій проблемі українські юристи, що набувають знань про міжнародний комерційний арбітраж виключно з українських (та російських) джерел, зазвичай не цілком адекватно розуміють суть та механізм міжнародного комерційного арбітражу, що відбувається поза межами України та СНД.

(C) В.Н. Петрина, 2019

* Volodymyr Petryna, Ph.D. in Law, Associate professor of the National Academy of Internal Affairs 